\title{
リフトバージによるケーソン進水工法 に関する実験的研究 \\ EXPERIMENTAL STUDY ON A METHOD OF CAISSON LAUNCHING BY THE SUBMERSIBLE LIFT BARGE
}

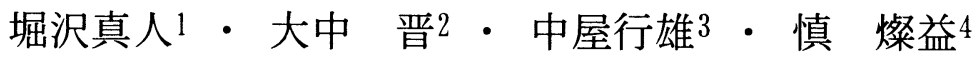 \\ 川上 治男 5 - 廣井康伸 6 \\ Makoto HORISAWA, Susumu ONAKA, Yukio NAKAYA, Chan Ik SHIN \\ Haruo KAWAKAMI, Yasunobu HIROI \\ 1正会員 東亜建設工業侏) 土木本部設計部（\%102-8451 東京都千代田区四番町 5 ） \\ ${ }^{2}$ 正会員 工修 東亜建設工業怢）土木本部設計部（T102-8451 東京都千代田区四番町 5)

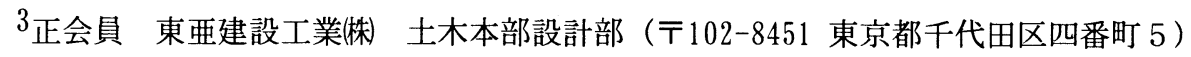 \\ ${ }^{4}$ 工博 長崎総合科学大学教授 船舶工学科（干851-0193 長崎市網場町 536) \\ 5 深田サルベージ建設侏（テ231-0005 横浜市中区本町1-8） \\ 6 長崎総合科学大学大学院工学研究科（干851-0193 長崎市網場町536)
}

\begin{abstract}
Hydraulic tests were conducted on the characteristics of motion of a buoyant caisson put on a semi-submersible lift barge to confirm the validity of a new caisson transporting and launching method by using a semi-submersible lift barge. It was found that the motion of the barge greatly decreases when it is semi-submerged, and that the motion of the buoyant caisson on the deck is influenced by the wave direction against the barge and the location of the caisson on the deck. Using these results, a safe launching method under wavy conditions was presented.
\end{abstract}

Key Words: ship motion, caisson motion, hydraulic test, lift barge

\section{1.はじめに}

防波堤や護岸に用いられるケーソンは，専用の製 作ヤードを持たない場所で建設する場合, 最寄り の既設ヤードで製作したものを海上運搬する方法 や，フローティングドックにより製作・進水する方 法で施工されるのが一般的である。しかし，これ らの方法ではケーソン曳航時の安全性の問題，係 留泊地確保の問題, 等が生じる. そこで, 半潜水 式のリフトバージを用いた新たなケーソン運搬・ 進水工法を提案した。これは，周辺ヤードで製作 したケーソンをバージごと施工地点まで曳航し， ケーソンを進水させる工法である．波浪中でケー ソンを進水させる場合，バージおよびケーソンの 両者の動摇が生じ，バージのデッキ面との接触に より，ケーソンを破損する恐れが考えられる、マ ウンド上におけるケーソンの波浪中挙動に関する 研究については, これまでいくつか行われている1 2). 一方, 波浪中で動摇しているバージ上における ケーソンの動摇特性を扱った事例は見られない.
そこで本研究は, バージ上でのケーソン進水時の 状況を水理実験により再現し, 波浪中でのバージ およびケーソンの動摇特性を把握するとともに, 最も安全性の高い進水方法を見出すことを目的と する.

\section{2. 本工法の概要}

図ー 1 は，本工法のイメージを図示したものであ る. 既設ヤードで製作されたケーソンを半潜水式 のリフトバージに搭載後 (a), 据付地点まで曳航し

（b），到着後，ケーソンが浮上するまでバージを 沈降させ (c), その後, 曳船によりケーソンを引き 出す（d）工法である. 本工法の特徵として, 以下 の点が挙げられる.

・長距離の間, ケーソンを曳航する必要がなく, 安 全な運搬が可能である.

・そのため, 専用のケーソンヤードを持たない地点 においても，周辺の既設ヤードを利用したケーソ ン製作が可能となる. 


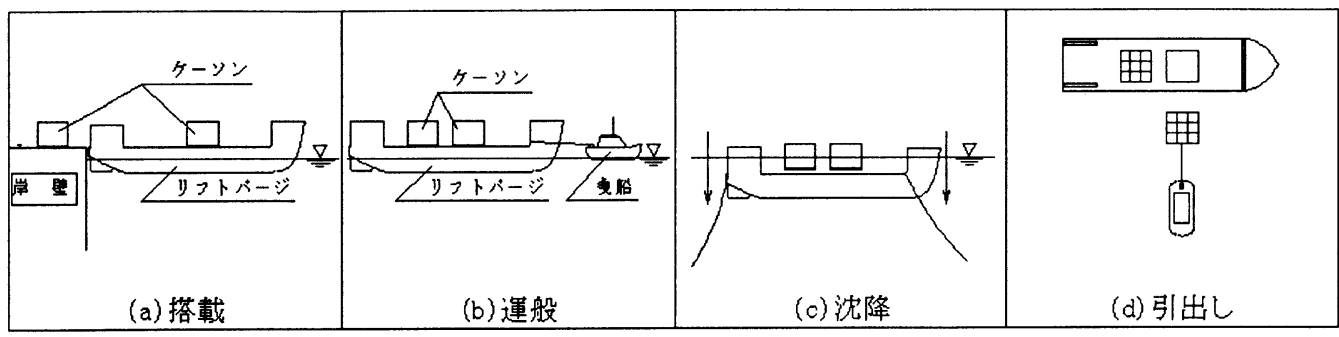

図ー 1 リフトバージによるケーソン運搬・進水工法のイメージ

\section{3. 実験内容}

実験は, 長さ $60 \mathrm{~m}$, 幅 $4 \mathrm{~m}$, 水深 $2.3 \mathrm{~m}$ の船舶海 洋試験水槽に，表一 1 に示す縮尺 $1 / 75$ のリフト バージおよびケーソン模型を用いて行った。図ー 2 に示すように，半潜水状態としたバージ上に ケーソンを浮遊させることにより，ケーソン進水 時の状況を再現した。ここで，ケーソン底部と バージデッキ面との余裕高（クリアランス）につ いては，現地換算で $1 \mathrm{~m}$ とた。なお両模型は， 波による運動を拘束しない程度の弱いバネを用い て係留した。リフトバージは，写真－1，2 2 に示 すように，それぞれ船側方向（ $\chi=90^{\circ}$ とする）， および船首方向（ $\chi=0^{\circ}$ とする）から波が作用 するように係留した，またケーソンは，引出し前 の状態として，バージのデッキ上にある状態（写 真一 1) と, 引出し途中の状態として, ケーソン 断面の半分がデッキ面にかかった状態（写真一 2) との 2 タイプで実験を行った.ここでケーソ ンの置き方は, 縦置き（ケーソンフーチング部が

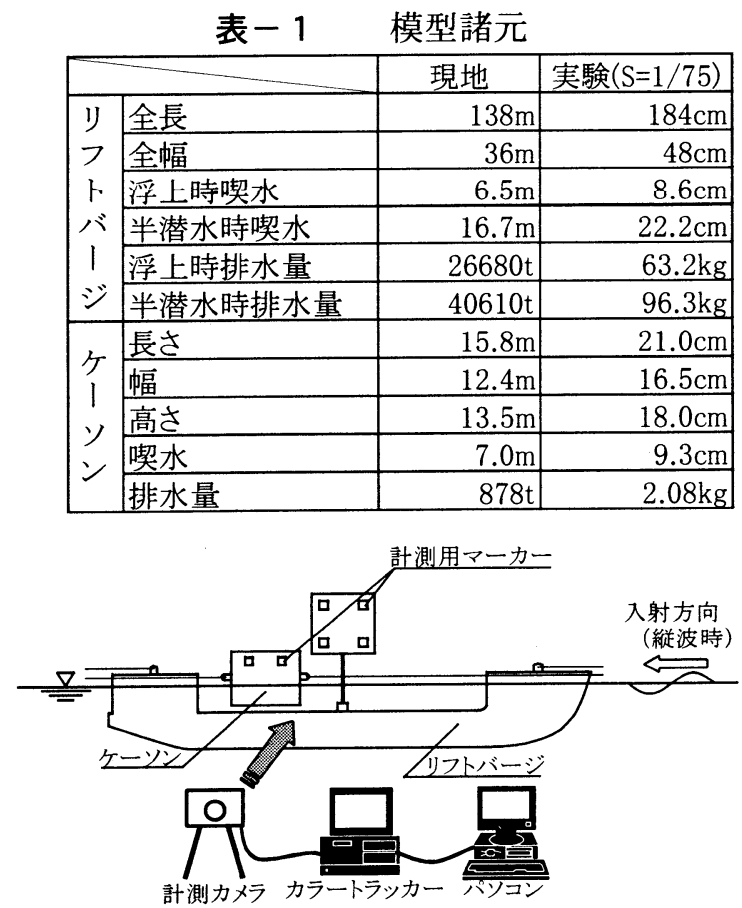

図-2 実験概要
水槽の側面側となる方向）および横置き（同，岸 沖側となる方向）の 2 とおりで行った。実験は規 則波および不規則波で行い，波高については規則 波については現地換算で $1 \mathrm{~m}$ と $2 \mathrm{~m}$ ，不規則波の 場合は $\mathrm{H}_{1 / 3}=1.3 \mathrm{~m}$ とし, 周期については数ケース

（同 5 〜 $20 \mathrm{~s}$ ） で行った. バージおよびケーソン の動摇計測には，2次元動態計測装置（カラート ラッカー）を用いた。これは，動摇計測対象物に ターゲットとしてのマーカーを設置し，これをC C Dカメラにより追跡することにより, 対象物の リアルタイムの二次元動的位置座標を計測するも のである．本実験では水槽の側面側にカメラを設 置することにより，リフトバージの運動としては, 写真－ 1 に示す $\chi=90^{\circ}$ の場合は, Roll（横摇）, Sway（左右摇）, Heave（上下摇）の3 成分が, ま た写真 -2 の $\chi=0^{\circ}$ の場合は, Pitch（縦摇）, Surge（前後摇）, Heaveの 3 成分が計測される.

\section{4. 実験結果}

（1）リフトバージの動摇特性
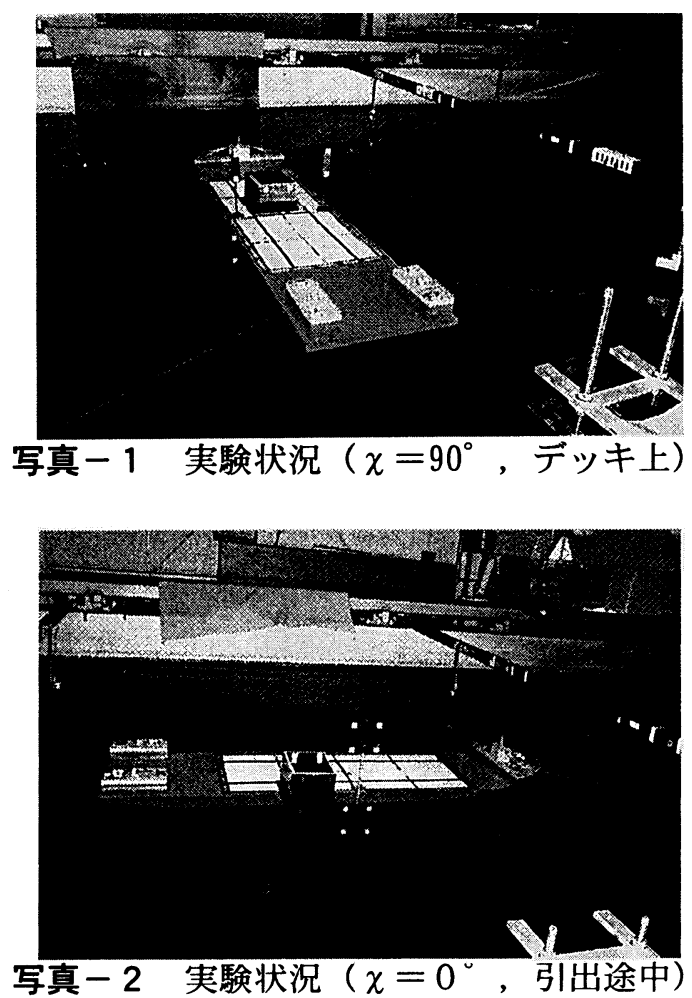


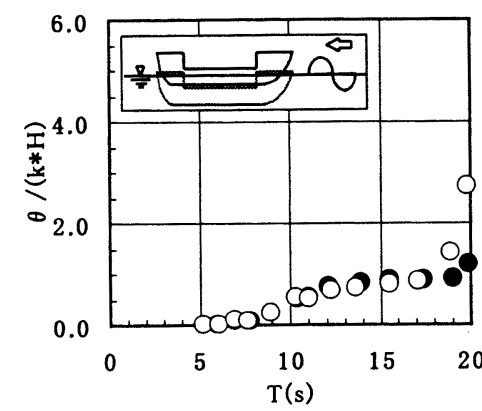

(1) Pitch

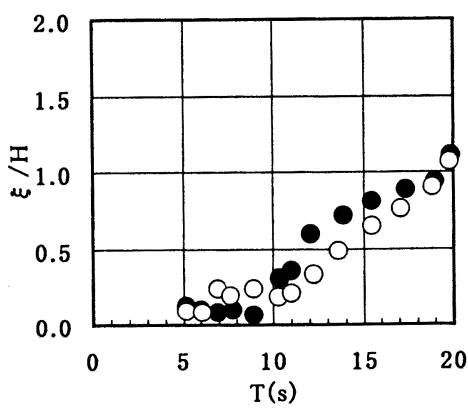

(2) Surge

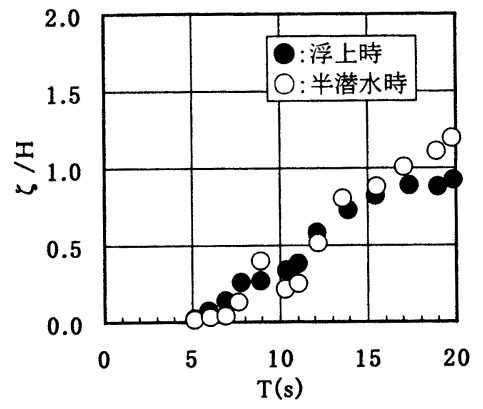

(3) Heave

図ー 3 バージの応答特性 $\left(\chi=0^{\circ}, \mathrm{H}=1 \mathrm{~m}\right)$

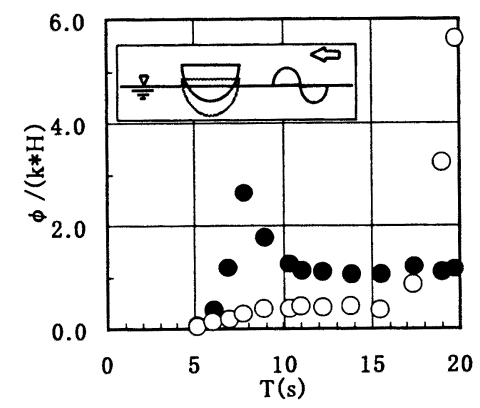

(1) Roll

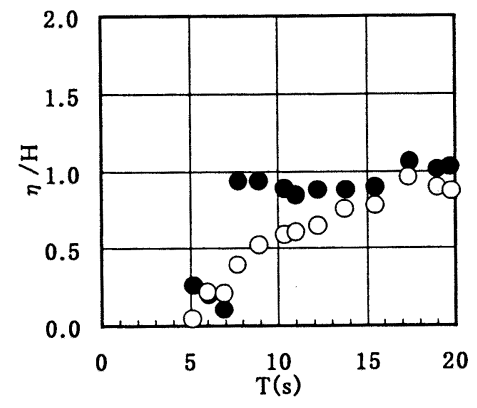

(2) Sway

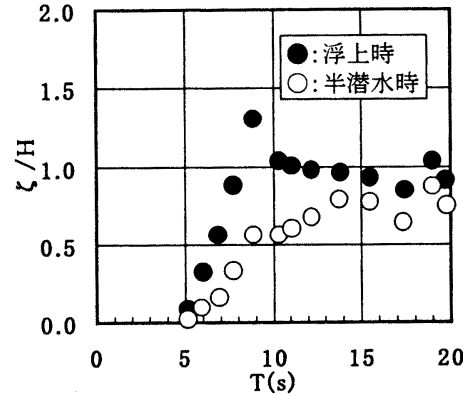

(3) Heave

図ー4 バージの応答特性 $\left(\chi=90^{\circ}, \mathrm{H}=1 \mathrm{~m}\right)$

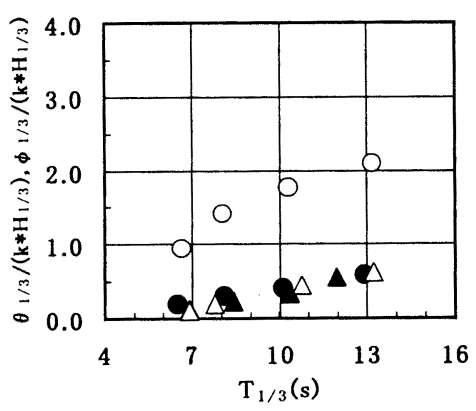

(1) Roll or Pitch

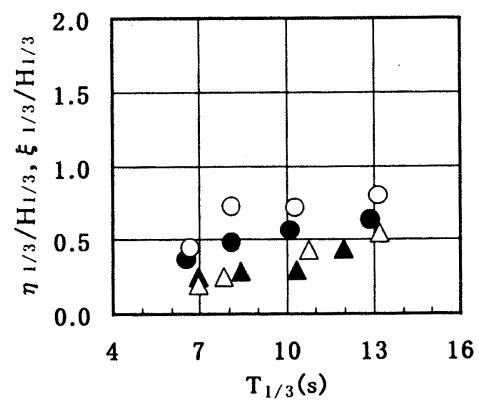

(2) Sway or Surge

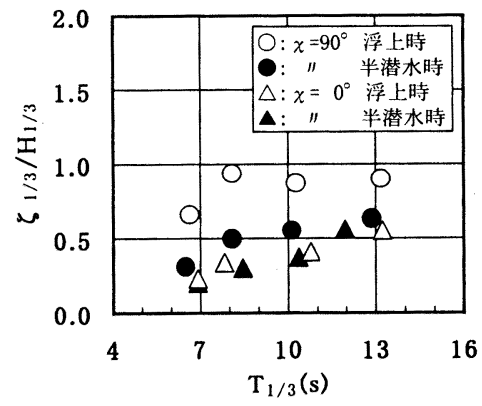

(3) Heave

図ー5 不規則波に対するバージの動摇統計量 $\left(\mathrm{H}_{1 / 3}=1.3 \mathrm{~m}\right)$

はじめに, リフトバージの動摇特性について示す. リフトバージは, ケーソン運搬時には浮上状態, 引 出時には半潜水状態と, 作業状況に応じて喫水が变 わる. 図一 3 は, $\chi=0^{\circ}$ ，波高 $1 \mathrm{~m}$ における浮 上状態, および半潜水状態のバージのPitch, Surge, およびHeaveに対する応答特性を示したものである. ここで縦軸は, Pitchについては波形勾配で, Surge およびHeaveについては入射波高で無次元化してい る. なお，それぞれの動摇量は全振幅を用いている. また, 横軸の周期は現地換算値である.これより $=0^{\circ}$ の場合, Surgeに多少の違いが見られ, 周期 の長いところで, 浮上状態では半潜水状態に比べて $2 \sim 3$ 割程度の動摇量の増加が見られる。一方 Pitchについては, 周期 $20 \mathrm{~s}$ 付近で, 半潜水状態の 場合に急激な動摇量の増加が見られるに対し, 浮上 状態ではそのような増加が見られない。これは，喫 水の違いにより付加質量および重心傾心間距離が変
化し，これに伴い，固有周期も変化するためと考え られる. またHeaveについては，喫水の違いによる 動摇量の顕著な違いは見られない.つぎに図一4は， $\chi=90^{\circ}$ におけるRoll， Sway，およびHeaveに対 する応答特性を示したものである.これより， $\chi=$ $0^{\circ}$ の場合に比べて喫水の違いによる動摇特性の明 瞭な違いが見られ, いずれの運動についても, 浮上 状態の結果が半潜水状態に比べて動摇量の顕著な増 加が見られる. 特に周期 $8 \sim 10 \mathrm{~s}$ 付近で, 浮上状態 の結果はいずれの運動についても著しく動摇量が増 加しているのに対し, 半潜水状態ではそのような増 加傾向が見られず, むしろ図一 3 に示す $\chi=0^{\circ}$ の 結果にほぼ近い特性が見られる。 なお, これらの結 果は波高 $1 \mathrm{~m}$ の結果のみ示したが, 波高 $2 \mathrm{~m}$ の場合 についても, 同調周期付近を除いてほぼ同様の応答 特性が得られた。これより, 今回の実験条件におい ては,バージの運動については, 波高に関してほぼ 


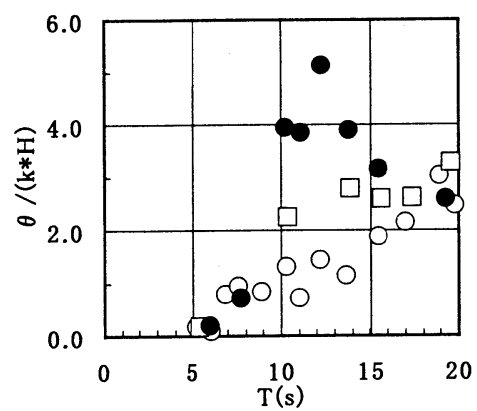

(1) Pitch

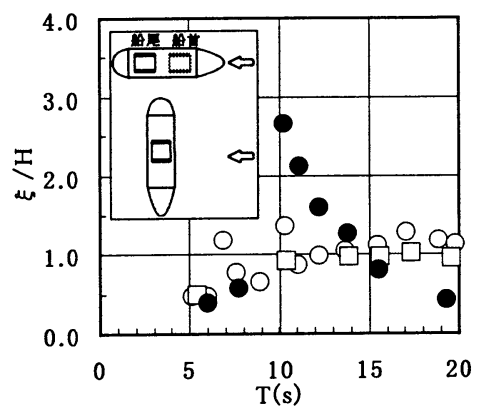

(2) Surge

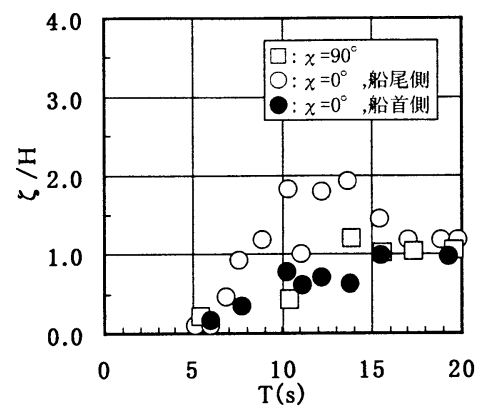

(3) Heave

図ー6 バージの向きの違いによるケーソン応答特性の比較 $(\mathrm{H}=1 \mathrm{~m})$

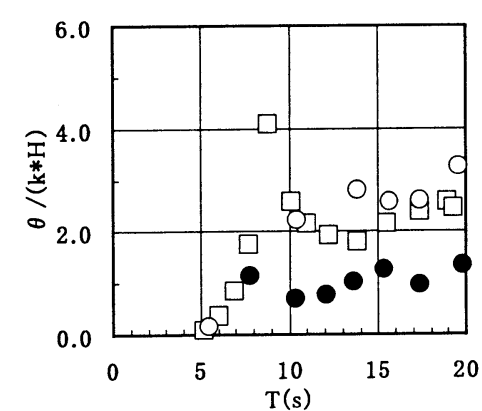

(1) Pitch

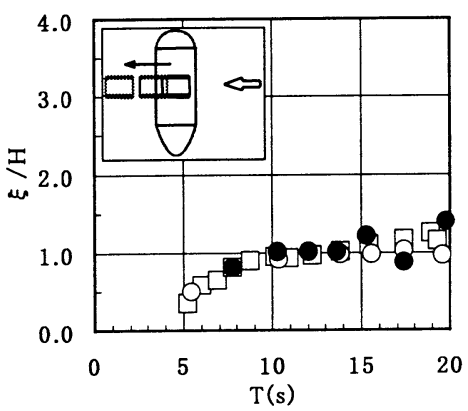

(2) Surge

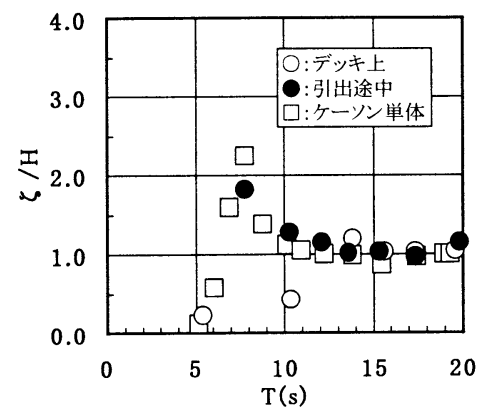

(3) Heave

図-7 引出し過程の違いによるケーソン応答特性の比較（ $\chi=90^{\circ}, \mathrm{H}=1 \mathrm{~m} ）$

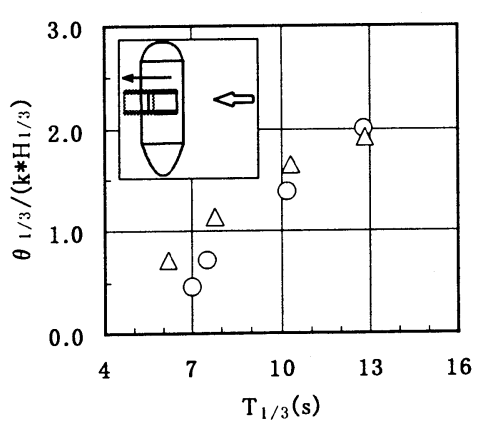

(1) Pitch

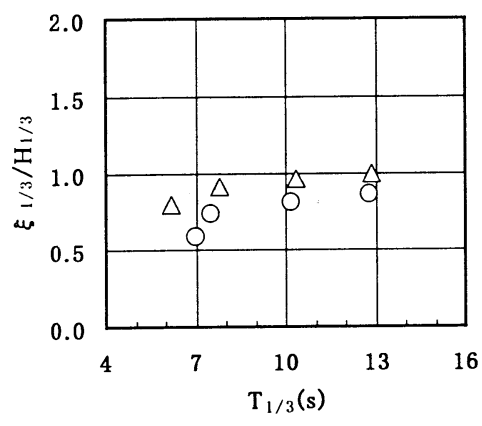

(2) Surge

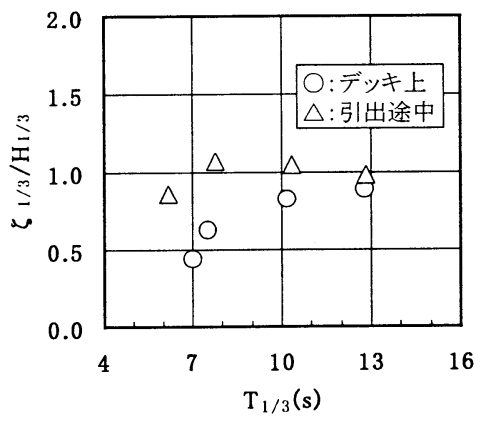

(3) Heave

図一 8 不䙺則波に対するケーソンの動摇統計量 $\left(\chi=90^{\circ}, \mathrm{H}_{1 / 3}=1.3 \mathrm{~m}\right)$

線形であるといえる.

つぎに, $\mathrm{H}_{1 / 3}=1.3 \mathrm{~m}$ に対する不規則波害験より 得られた動摇統計量について示したものが図ー5で ある.ここで統計量としては, それぞれの動摇の全 振幅に対する有義值を用いている。これより応答特 性と同様, $\chi=0^{\circ}$ の場合は浮上状態, 半潜水状態 の違いは見られない. 一方 $\chi=90^{\circ}$ では, 両者の違 いは顕著となり,いずれの運動も浮上状態の結果が 著しく増加している. また半潜水状態では波の作用 方向の違いによる動摇量の顕著な違いは見られない.

以上の結果より, 運搬時の浮上状態においては, $\chi=90^{\circ}$ の場合にに比べて $\chi=0^{\circ}$ の場合の方が バージの動摇量は小さくなる. 一方進水時の半潜水 状態においては, $\chi=0^{\circ}, 90^{\circ}$ の場合とも動摇量 は小さく, またその特性も両者であまり変わらない ことがわかった.

\section{（2）進水時のケーソン動摇特性}

つぎに, 進水時におけるケーソンの動摇特性につ いて示す. リフトバージ上でのケーソンの動摇は, 波に対するバージの向き, デッキ上でのケーソン搭 載位置, 向き等の影響を受けると考えられる. また, ケーソンがバージ上にある場合, 引出し途中（ケー ソンの一部がバージにかかった状態）, さらに引出 し後（ケーソン単体の状態）といった, 引出し過程 の違いによっても動摇特性は異なると考えられる. そこで, ここではバージの向きの違い, およびケー ソンの引出し過程の違いに着目して比較を行った.

\section{a）バージの向きの違いによる比較}

図一 6 は, $\mathrm{H}=1 \mathrm{~m}$ の場合の, バージの向きの違 いに対するケーソンの応答特性を示したものである. 図中の $\square$ 印は $\chi=90^{\circ}, \bigcirc$ 印は $\chi=0^{\circ}$ でケーソン 


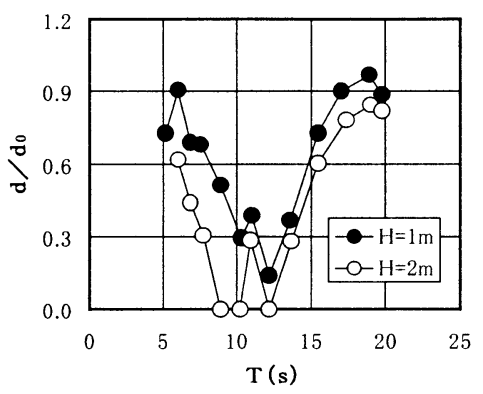

(1) 余裕高

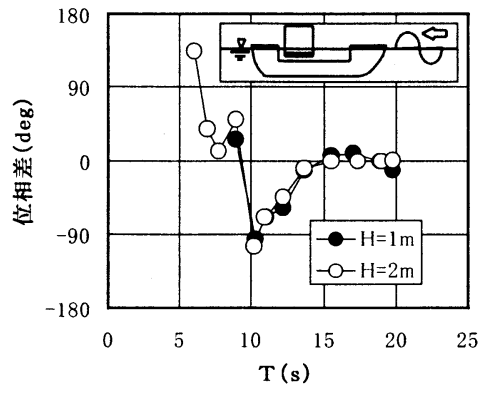

(2) 位相差

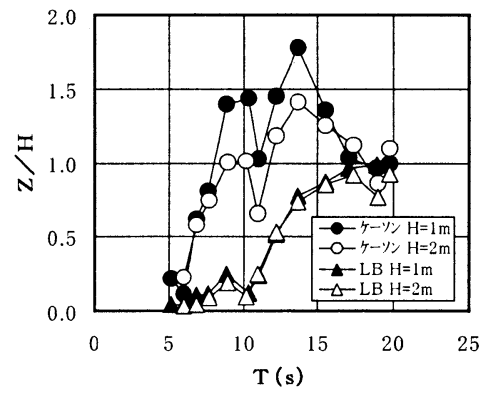

（3）鈶直変位振幅

図-9 余裕高, 位相差および鉛直変位振幅の応答特性 $\left(\chi=0^{\circ}\right)$

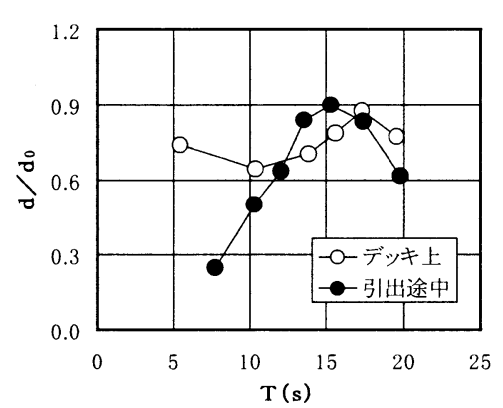

(1) 余裕高

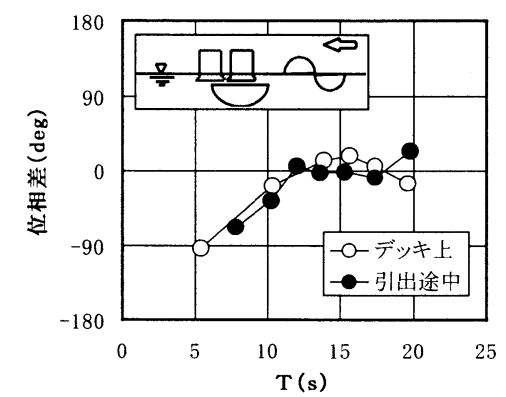

(2) 位相差

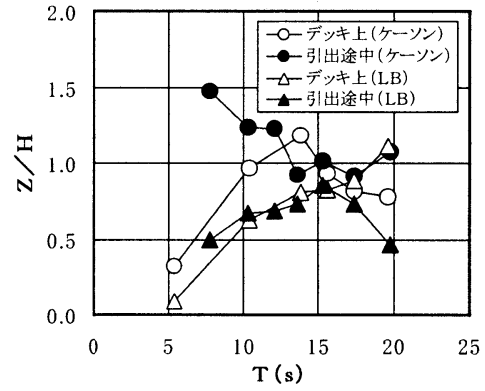

（3）鈆直変位振幅

図-10 余裕高, 位相差および鉛直変位振幅の応答特性 $\left(\chi=90^{\circ}, \mathrm{H}=1 \mathrm{~m}\right)$

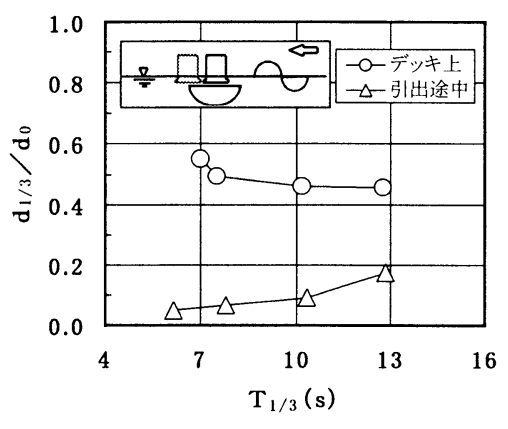

（1）余裕高

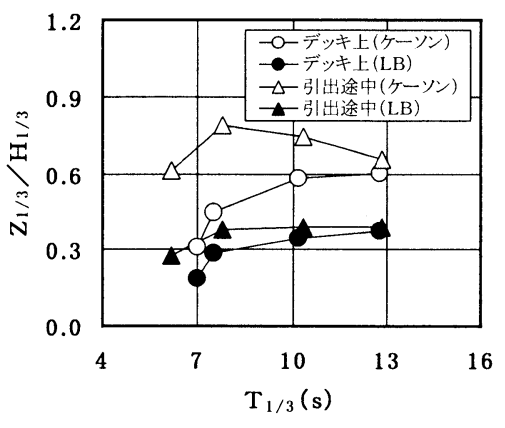

（2）鈶直変位振幅

図-11 不規則波に対する余裕高および鉛直変位振幅 $\left(\chi=90^{\circ}, \mathrm{H}_{1 / 3}=1.3 \mathrm{~m}\right)$

搭載位置が船尾側の結果を，○印は船首側の結果を 示す。なおケーソンの搭載方向としては, 縦置き （ケーソンのフーチング部が水槽側面側となる方 向）とした.これより， $\chi=0^{\circ}$ の場合，ケーソン の搭載位置により動摇特性は大きく異なっている. この原因として, ケーソン搭載位置の違いにより, バージの動摇との位相関係が異なること, および バージの船首部分からの回折波等の影響により, 波 の場が船首側と船尾側とで異なることが考えられる. これに対し $\chi=90^{\circ}$ の場合は, バージの動摇との位

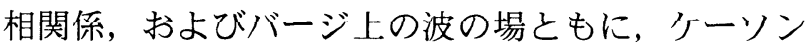
搭載位置が異なってもバージ上ではほぼ一様である. その結果, どの場所にケーソンを搭載しても， $\chi=$ $0^{\circ}$ のときに見られるような, ケーソンの動摇特性 の顕著な違いは生じないと考えられる.

\section{b）引出し過程の違いによる比較}

つぎに，引出し前のケーソンがデッキ上にある状 態, 引出し途中の状態, および引出し後のケーソン
単体の状態での比較を行う. 図ー 7 は, $\mathrm{H}=1 \mathrm{~m}$, $\chi=90^{\circ}$ の場合における, ケーソンのPitch, Surge およびHeaveの応答特性を示したものである。これ より, Pitchについては引出し後のケーソン単体状 態の場合には, $9 \mathrm{~s}$ 付近に明瞭なピークが存在する のに対し，デッキ上，引出し途中とも，そのような ピークは見られない. Surgeについては, 引出し前 後での顕著な違いは見られない. またHeaveについ ては, ケーソン単体状態では $8 \mathrm{~s}$ 付近に動摇のピー クが存在するのに対し, デッキ上にある場合では, そのようなピークは見られない。また引出し途中の 結果はケーソン単体の結果に近い. なお， $\chi=0^{\circ}$ の場合についても, ほぼ同様の傾向が見られたが, 引出し途中の場合に, 波の進行方向と直交する方向 での回転運動が非常に顕著となり，デッキ上にある 場合に比べて激しい動摇が生じた。このような回転 運動は, 特に周期が短いほど顕著となり,これによ り, 周期 $15 \mathrm{~s}$ 以下ではケーソン底部がバージデッキ 
面に激しく衝突する状況が見られた。これは $\chi=$ $0^{\circ}$ の場合, 波の進行方向と直交する方向で, デッ キ面の有無によりケーソンの付加質量が変わること や，波の場がデッキ面の外側と内側とで急激に変化 することによるものと考えられる.

つぎに図ー8は，ケーソンがデッキ上および引出 し途中の状態における, 不規則波に対する動摇統計 量を示したものである. これより, Pitch, Heaveに ついて $\mathrm{T}_{1 / 3}=10 \mathrm{~s}$ 以下で, 引出し途中の結果がデッ キ上にある場合に比べて動摇量の増加が見られる.

しかしながら, 周期が長くなるにつれて, その差は 小さくなっていく.

以上の結果より, ケーソンの動摇は, バージデッ キ上にある場合よりも, 引出し途中の方が大きく, より危険な状態となることがわかった. 特に $\chi=$ $0^{\circ}$ の場合は, 波の進行方向と直角方向の回転運動 が加わり， $\chi=90^{\circ}$ の場合に比べて，より激しい動 摇となることがわかった.

c)ケーソンとデッキ面との衝突の可能性

ケーソン進水時において, 最も危惧されるのは, ケーソンおよびリフトバージの波浪中の動摇により, 両者が衝突し, その結果, ケーソン底部が破損する ことである．そこでつぎに，ケーソン底部とデッキ 面との余裕高（クリアランス）について検討した. 図一 9 は, $\chi=0^{\circ}$ における $\mathrm{H}=1 \mathrm{~m}$ おび $2 \mathrm{~m}$ の ケーソン下端中央部における余裕高（ $\mathrm{d}$ とする）, 両者の位相差および鉛直変位振幅の応答特性を示し たものである.ここで $\mathrm{d}_{0}$ は初期状態における余裕 高（=1 m） を示す。これより位相差には明瞭な周 波数特性が見られ，位相差が最も大きいところで余 裕高は小さくなり，位相差が 0 の場合は，鉛直動摇 振幅の減少とともに余裕高は大きくなる．またケー ソン鉛直変位は, 波高の大きい方が，粘性抵抗の影 響と考えられる振幅の減少が見られる.このように 余裕高は，ケーソン及びリフトバージ各々の鉛直方 向の動摇振幅とともに，両者の位相差に支配される. つぎに $\chi=90^{\circ}, \mathrm{H}=1 \mathrm{~m}$ に対し，ケーソンがデッ キ上にある場合と引出し途中の場合とを比較したも のが図ー10である.これより余裕高は, 周期の短い ところで, 引出し途中の方がデッキ上の場合に比べ て小さくなっている.これは，ケーソンの鉛直変位

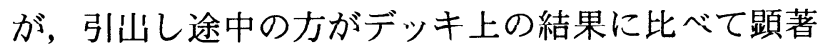
に増加していることに対応する. なお， $\chi=90^{\circ}$ の 場合の位相差については，両者ともほぼ同様の特性 となった. また, 同じ $\chi=90^{\circ}$ の場合の, $\mathrm{H}_{1 / 3}=$ $1.3 \mathrm{~m}$ の不規則波に対する引出し前後の結果を示し たものが図一11である. なお，この場合の余裕高， 鈶直変位振幅としては有義値を用いている．不規則 波の場合，両者の位相はほぼランダムであると見な せるため, 余裕高は各々の鉛直変位振幅のみに依存 すると考えられる.これより，ケーソンの鉛直変位 は引出し途中の方が, デッキ上にある場合に比べて 大きくなっている. その結果, 余裕高は小さくなり, より接触しやすい状況となることがわかる.

\section{5. おわりに}

本研究で得られた結論はつぎのとおりである.

1)リフトバージの波浪中での挙動は, 喫水の違い や波の入射方向の違いにより異なる。波が船横 から作用する $\chi=90^{\circ}$ の場合, バージが浮上状 態の場合には比較的動摇量が大きかったものが, 半潜水状態では格段に低下する. 一方, 波が船 首から作用する $\chi=0^{\circ}$ の場合は, $\chi=90^{\circ}$ の ときに見られたような浮上時, 半潜水時での動 摇特性の顕著な違いは見られず，両者とも比較 的動摇量が小さい.

2) 進水時におけるケーソンの挙動は, 波に対する バージの向き, ケーソン搭載位置, 搭載方向の 違いによる影響を受ける. 特に $\chi=0^{\circ}$ の場合 は, ケーソンの搭載位置の違いにより, リフト バージの動摇変動との位相が異なることや, 船 首からの回折波によりデッキ上での波の場が場 所的に異なること, などにより動摇特性が大き く変化する. また引出し途中では, ケーソンの 付加質量や作用する波の急激な変化により, 波 の進行方向と直角方向での顕著な回転運動が生 じる.これに対し $\chi=90^{\circ}$ の場合は, このよう な現象は生じない.

3）ケーソン底面とバージデッキ面との接触の可能 性は, 引出し前のデッキ上にある場合に比べて, 引出し途中の方が高くなる. また $\chi=0^{\circ}$ にお いては, これに加えて波と直交する方向での顕 著な回転運動により, 接触の危険性がより高く なる.

以上の結果より, ケーソン運搬時は, バージの船 首から波を受ける方向で曳航し, 進水時において は，バージの船横から波が作用するように係留し， 波の進行方向に引き出す方法が，より安全である ことが示された.

謝辞 : 本研究の水理実験は, 深田サルベージ建設(侏) の高島栄一氏, および研究当時, 長崎総合科学大 学船舶工学科 4 年生の赤島 豊, 青野豪紀, 越智裕 也の諸氏らが中心となって実施したものである. ここに記して，感謝の意を表する次第である.

\section{参考文献}

1) 堀沢真人, 佐藤典之, 大橋裕寿, 赤村重紀, 坂間茂, 吉倉敬治 : ケーソン沈設過程の波浪中挙動, 海岸工学 論文集, Vol.43, pp. 1001-1005, 1996.

2)石崎崇志, 荒木英二, 藤原隆一, 倉田克彦, 永田修一 吉田尚史, 田中 洋 : ケーソンの曳航・据付時の動摇 および索張力, 海岸工学論文集, Vol.46, pp.841-845, 1999. 